\title{
Utility of a Reverse Double-drift Structure for Fabricating GaN IMPATT Diode Operating in the Terahertz Regime
}

\author{
Sahanowaj Khan ${ }^{1, *}$, Rishav Dutta ${ }^{2, \dagger}$, Aritra Acharyya ${ }^{3}$, Arindam Biswas ${ }^{2}$, \\ Hiroshi Inokawa ${ }^{4, \star}$, and Rudra Sankar Dhar ${ }^{1}$ \\ ${ }^{1}$ Department of Electronics and Communication Engineering, National Institute of Technology, Chaltlang, \\ Aizawl, Mizoram 796012, India \\ 2 School of Mines and Metallurgy, Kazi Nazrul University, Asansol, Burdwan, West Bengal 713340, India \\ ${ }^{3}$ Department of Electronics and Communication Engineering, Cooch Behar Government Engineering College, \\ Cooch Behar, West Bengal 736170, India \\ ${ }^{4}$ Research Institute of Electronics, Shizuoka University, Hamamatsu 4328011, Japan
}

(Received 21 March 2021; revised manuscript received 16 June 2021; published online 25 June 2021)

\begin{abstract}
Utility of the reverse double-drift region (DDR) structure has been studied for fabricating the gallium nitride impact avalanche transit time (IMPATT) diode operating at 1.0 terahertz (THz). Static and largesignal simulations have been carried out in order to verify the $\mathrm{THz}$ capabilities of conventional (normal) and reverse DDR structures. It is revealed that IMPATT operation is only possible in a reverse GaN DDR structure due to the lower value of series resistance of it as compared to the normal GaN DDR structure. Normal DDR GaN IMPATT cannot be operational at THz regime. Earlier, the authors had calculated the series resistance of conventional GaN DDR IMPATT diode designed to operate at $1.0 \mathrm{THz}$, however. They did not take into account the current crowing and spreading resistance at the ohmic metal contacts. That is why, the results were misleading. Those results lead to the conclusion that conventional $\mathrm{THz} \mathrm{GaN}$ DDR IMPATT may produce sufficient effective negative resistance since the series resistance of it remains within the range of 1.5-2.0 $\Omega$. In this paper, authors have proposed a reverse DDR IMPATT structure exclusively for $\mathrm{GaN}$ material and $\mathrm{THz}$ frequency bands. By using this reverse DDR structure, $p^{+}$-GaN $\sim \mathrm{Ni} / \mathrm{Au}$ contact can obtain a sufficient contact area, so that the anode-contact resistance can be minimized. A nonsinusoidal voltage-excited large-signal model developed by the authors has been used to study the static (DC) and large-signal properties of conventional and reverse DDR structures at $1.0 \mathrm{THz}$. The present study on the evaluation of $\mathrm{THz}$ source seems to open a new horizon for $\mathrm{THz}$ researchers and scientists.
\end{abstract}

Keywords: Double-drift region, GaN, IMPATT, Reverse DDR, Terahertz.

DOI: $10.21272 /$ jnep.13(3).03014

PACS numbers: 42.55.Px, 45.70.Ht

\section{INTRODUCTION}

Several researchers have already explored the terahertz $(\mathrm{THz})$ proficiencies of gallium nitride $(\mathrm{GaN})$. Especially, the potentialities of impact avalanche transit time (IMPATT) diodes based on $\mathrm{GaN}$ as $\mathrm{THz}$ sources are already well known [1-4]. The IMPATT diode can produce very small magnitude of negative resistance $\left(\left|R_{d}\right|<10 \Omega\right)$ at $\mathrm{THz}$ regime. Therefore, the positive parasitic series resistance of the $\mathrm{THz}$ diode must be very small $\left(R_{s}<\left|R_{d}\right|\right)$ in order obtain significant output power at $\mathrm{THz}$ frequencies. The primary components of $R_{s}$ are un-swept depletion layers, $n^{+}$ and $p^{+}$-contact layers and contact resistances due to anode and cathode ohmic metal contacts [5]. Very low resistivity of $n^{+}$-GaN and $\mathrm{Ti} / \mathrm{Al} / \mathrm{Ti} / \mathrm{Au}$ ohmic contact can be achieved $\left(\sim 10^{-8}-10^{-6} \Omega \cdot \mathrm{cm}^{2}\right)$ [6]. But sufficiently low resistivity of $p^{+}$-GaN and $\mathrm{Ni} / \mathrm{Au}$ ohmic contact is very difficult to achieve; the minimum achievable resistivity remains of the order of $10^{-3}-10^{-2} \Omega \cdot \mathrm{cm}^{2}$ [7]. Therefore, in order to keep the overall series resistance sufficiently low, the area of $p^{+}-\mathrm{GaN} \sim \mathrm{Ni} / \mathrm{Au}$ contact must be as high as possible. In conventional $n^{+}-n-p-p^{+}$ DDR structure having $p^{+}$-layer at the top may not pro- vide sufficient contact area to the $p^{+}-\mathrm{GaN} \sim \mathrm{Ni} / \mathrm{Au}$ contact, especially at the $\mathrm{THz}$ frequencies. For this study, the material parameters of GaN are taken for the simulation from recently published literature [8-15].

\section{REVERSE DOUBLE-DRIFT STRUCTURE}

A conventional GaN based DDR IMPATT structure is shown in Fig. 1a [8].

The initial substance is a $p$-type GaN substrate. An $n^{+}$-buffer layer of around $10 \mu \mathrm{m}$ thickness can be grown on the $p$-GaN substrate; the donor concentration of $n^{+}$buffer layer is $2.0 \times 10^{24} \mathrm{~m}^{-3}$. Next, the $n^{+}, n, p$, and $p^{+}$. layers are successively grown on the $n^{+}$-buffer layer in order to form a conventional DDR structure; thickness and doping concentration of each layer are shown in Fig. 1a. Anode is formed by depositing $\mathrm{Ni} / \mathrm{Au}$ on $p^{+}$layer, and similarly the cathode is formed by depositing $\mathrm{Ti} / \mathrm{Al} / \mathrm{Ti} / \mathrm{Au}$ on $n^{+}$-buffer layer (a ring-shaped cathode structure is elaborately described in an earlier paper [8]). In the reverse DDR IMPATT structure, the order of layers of conventional DDR is reversed; it is shown in Fig. 1b. Here, the initial substance is $n$-type GaN substrate over which a $p^{+}$-buffer layer can be deposited.

\footnotetext{
*khannowda84@gmail.com

†dutta.rishav17@gmail.com

‡ inokawa.hiroshi@shizuoka.ac.jp

The results were presented at the International Conference on Innovative Research in Renewable Energy Technologies (IRRET-2021)
} 
The other layers like $p^{+}, p, n$ and $n^{+}$-layers can be deposited as per Fig. 1b. The Ti/Al/Ti/Au cathode can be deposited on top $n^{+}$-layer and $\mathrm{Ni} / \mathrm{Au}$ ring-shaped anode can be deposited on $p^{+}$-buffer layer.

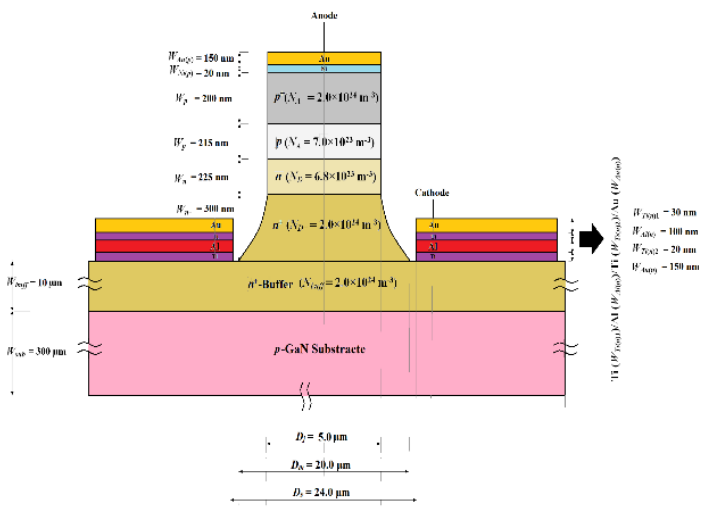

(a) DDR

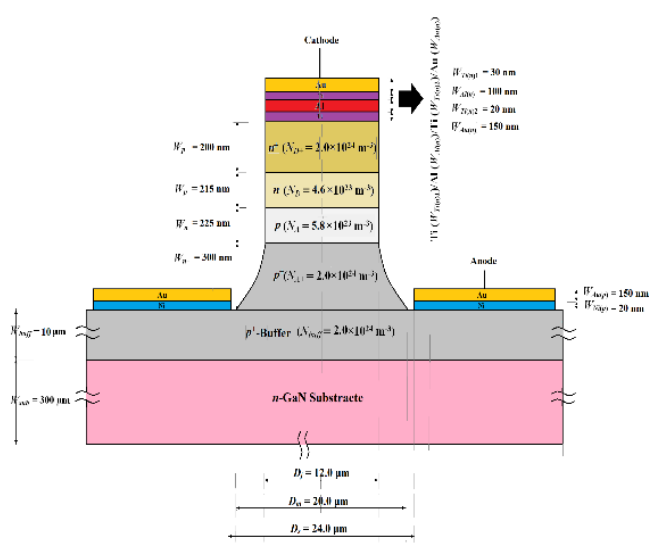

(b) Reverse DDR

Fig. 1 - Schematic diagram showing the vertical section of the 1.0-THz GaN IMPATT diodes having (a) normal and (b) reverse DDR structures

\section{STATIC ANALYSIS}

The static (DC) analysis of the $1.0 \mathrm{THz}$ GaN based conventional and reverse DDR diodes are carried out for the bias current range of 56.55-395.84 mA. The variation of electric field and electric potential with spatial distance are shown in Fig. $2 \mathrm{a}$, b. Here, the $p-n$ junction is located at $x=0 ; p$ - and $p^{+}$-layers are extended along the $+x$-axis and $n$ - and $n^{+}$-layers are extended along the $-x$-axis. Since the structural and doping parameters of both the diodes are assumed to be identical, thus both of those must have same electric field and electric potential profiles at a particular bias current. The field profiles ensure the fact that the $p$-side of the diodes is more affected due to the space charge phenomena as compared to the $n$-side of those. It is due to the higher ionization rate of hole as compared to electrons in $\mathrm{GaN}$ [12]. The variations of the breakdown voltage $\left(V_{B}\right)$, avalanche zone voltage $\left(V_{A}\right)$ and total voltage drop across drift zone $\left(V_{D}\right)$ with bias current are shown in Fig. 3a. Fig. 3b shows the avalanche $\left(x_{A}\right)$ and total drift zone $\left(x_{D}\right)$ widths versus bias current; the inset in Fig. $3 \mathrm{~b}$ shows the ratios $x_{A} / W, x_{D} / W$ and $V_{D} / V_{B}$
( $\left.W=W_{n}+W_{p}\right)$ versus $I_{0}$ plots. All these plots indicate the significant broadening of the avalanche layer with an increase in the bias current.

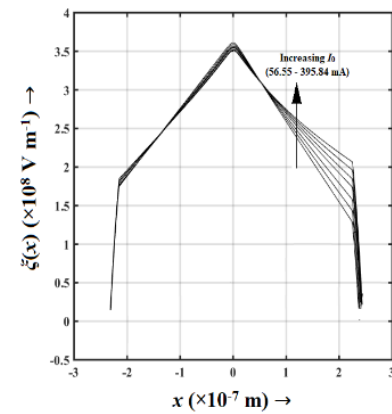

(a)

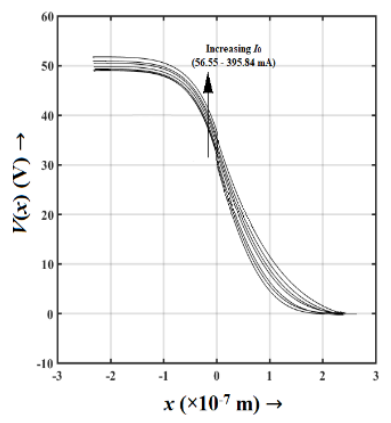

(b)
Fig. 2 - (a) Electric field and (b) potential profiles (i.e., $\xi(x)$ vs. $x$ and $V(x)$ vs. $x$, respectively) of $1.0-\mathrm{THz}$ GaN IMPATT diodes for different bias currents $\left(I_{0}\right)$

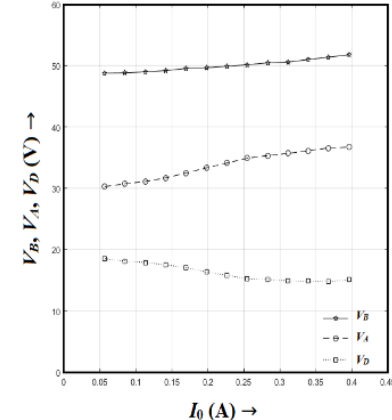

(a)

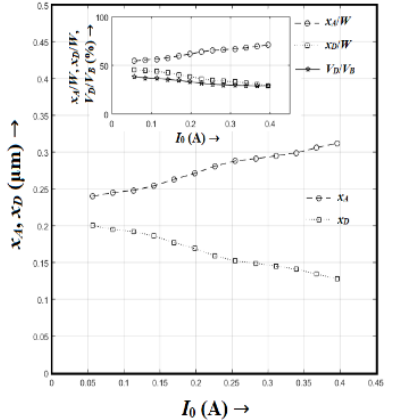

(b)
Fig. 3 - Variations of the (a) breakdown voltage $\left(V_{B}\right)$, avalanche zone voltage drop $\left(V_{A}\right)$, total voltage drop across drift zones $\left(V_{D}\right)$ and (b) avalanche zone width $\left(x_{A}\right)$, total width of the drift zones $\left(x_{D}\right)$ with bias current density. The inset in Fig. 3b shows the variations of $x_{A} / W, x_{D} / W$ and $V_{D} / V_{B}$ with bias current density (where $W=W_{n}+W_{p}$ )

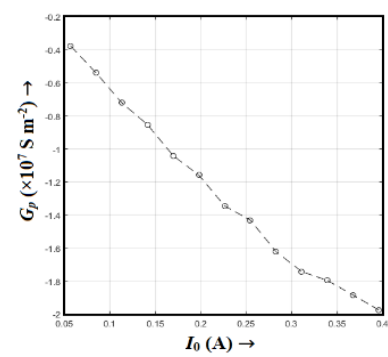

(a)

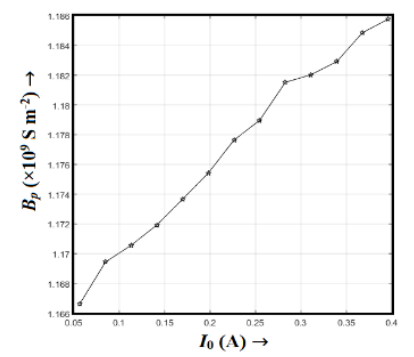

(b)
Fig. 4 - Variations of the (a) peak negative conductance $\left(G_{p}\right)$, and (b) corresponding susceptance $\left(B_{p}\right)$ with bias current density assuming $R_{s}=0$

\section{LARGE-SIGNAL ANALYSIS}

The admittance characteristics of the diodes without considering the parasitic series resistance are obtained from the large-signal simulation for different bias currents (Fig. 4). It is noted that the sensitivity of the magnitude of negative conductance $\left(G_{p}\right)$ of the diodes with respect to the bias current is significantly higher as compared to that of the susceptance $\left(B_{p}\right)$. This indicates reduction of quality factor $\left(Q=-B_{p} / G_{p}\right)$ 


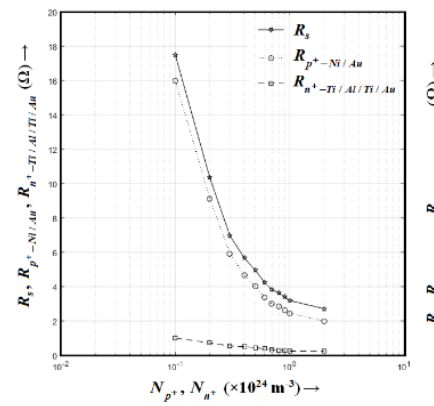

(a)

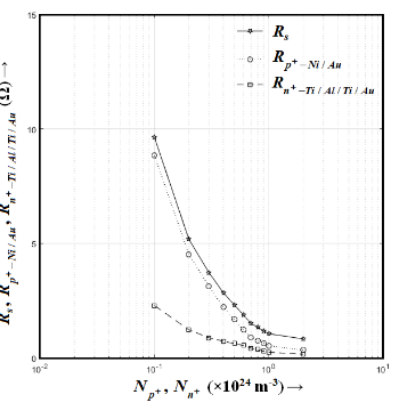

Fig. 5 - Variations of the total series resistance, resistance due to $p^{+}-\mathrm{Ni} / \mathrm{Au}$ and $n^{+}$-Ti/Al/Ti/Au contacts in (a) normal and (b) reverse DDR diode with doping concentrations of $n^{+}$-layer and $p^{+}$-buffer layer for $282.74 \mathrm{~mA}$ bias current (here $\Delta D=\left(D_{s}-D_{m}\right) / 2=2 \mu \mathrm{m}$ and $\left.W_{\text {buff }}=10 \mu \mathrm{m}\right)$

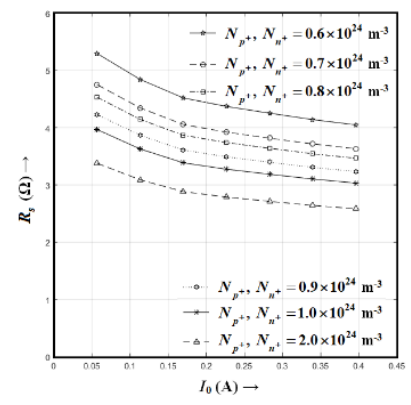

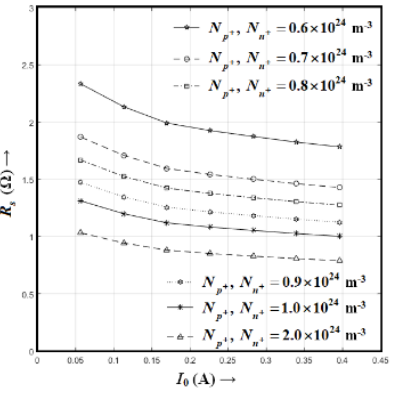

Fig. 6-Variations of the total series resistance with bias current in (a) normal and (b) reverse DDR diode for different doping concentrations of $n^{+}$-layer and $p^{+}$-buffer layer

at higher bias current; therefore, the avalanche growth rate will be significantly higher as higher bias currents.

The contact resistances at anode and cathode contacts are calculated by using the exact field solution by following the method prescribed by Zhang et al. [16]; the current crowding and spreading resistance in the thin film contacts are taken into consideration. The parasitic series resistances due to the un-swept depletion layers are calculated by using the method proposed by the authors in their earlier papers [17]; the said method takes into account the effect of depletion with modulation under largesignal condition and the influence of skin effect at $\mathrm{THz}$ frequencies. The total series resistance $\left(R_{s}\right)$, resistance due to $p^{+}-\mathrm{Ni} / \mathrm{Au}\left(R_{p+-\mathrm{Ni} / \mathrm{Au}}\right)$ and $n^{+}$-Ti/Al/Ti/Au $\left(R_{n+-\mathrm{Ti} / \mathrm{A} / \mathrm{Ti} / \mathrm{Au})}\right)$ contacts are calculated for different $n^{+}$- and $p^{+}$-doping

\section{REFERENCES}

1. A.K. Panda, R.K. Parida, N.C. Agarwala, and G.N. Dash, 2007 Asia-Pacific Microwave Conference, 1-4, 2007.

2. A.K. Panda, D. Pavlidis, and E. Alekseev, IEEE Trans. Electron Dev. 48, 820 (2001).

3. S. Banerjee, M. Mukherjee, and J.P. Banerjee, Int. J. Adv. Sci. Technol. 16, 12 (2010).

4. Aritra Acharyya, J.P. Banerjee, Appl. Nanosci. 4, 1 (2014).

5. Aritra Acharyya, Suranjana Banerjee and J.P. Banerjee, Int. Journal Microwave Wireless Technol. 5 No 1, 91 (2013).

6. D.F. Wang, F. Shiwei, C. Lu, A. Motayed, M. Jah, S.N. Mohammad, K.A. Jones, and L.S. Riba, J. Appl. Phys. 89, 6214 (2001).

7. Ho Won Jang, Soo Young Kim, and Jong-Lam Lee, J. Appl. Phys. 94, 1748 (2003).

8. A. Biswas, S. Sinha, A. Acharyya, A. Banerjee, S. Pal, H. Satoh, concentrations $\left(N_{n+}, N_{p^{+}}\right)$. The parameters $R_{s}, R_{p+-\mathrm{Ni} / \mathrm{Au}}$ and

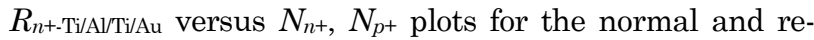
verse DDR diodes are shown in Fig. $5 \mathrm{a}$ and Fig. 5b, respectively. Also, the total series resistance of the normal diodes for different $n^{+}$- and $p^{+}$-doping levels are plotted against bias current $\left(I_{0}\right)$ in Fig. 6. It is noteworthy from above-mentioned figures that the series resistance of the normal DDR diodes is significantly higher as compared to its reverse counterpart. Here, $R_{p+-\mathrm{Ni} / \mathrm{Au}}$ is the dominant term in $R_{s}$, where $R_{s}=R_{d}+R_{p^{+}}+R_{n+}+R_{p+\mathrm{Ni} / \mathrm{Au}}++R_{n+}$ Ti/Al/Ti/Au; $R_{d}, R_{p^{+}}$and $R_{n+}$ are the series resistances due to un-swept depletion layers, $p^{+}$- and $n^{+}$-layers, respectively). Since the area of the anode contact is very small in normal DDR diode, the value of $R_{p+-\mathrm{Ni} / \mathrm{Au}}$ becomes very high at a particular value of $N_{p^{+}}$. Also, the specific contact resistivity of $p^{+}-\mathrm{Ni} / \mathrm{Au}$ contact is much higher as compared to that of $n^{+}-\mathrm{Ti} / \mathrm{Al} / \mathrm{Ti} / \mathrm{Au}$ contact. As a result of that it is a wise decision to provide much higher contact area to the $p^{+}$-Ni/Au contact in order to nullify the significantly higher specific contact resistivity of it. And this significantly higher anode contact area is provided in the reverse DDR diodes. As a result of that, a significantly lower $R_{s}$ is achieved in the reverse DDR diode as compared to its normal counterpart.

\section{CONCLUSIONS}

It is revealed in the current study that IMPATT operation is only possible in reverse GaN DDR structure due to the lower value of series resistance of it as compared to the normal GaN DDR structure; normal DDR GaN IMPATT cannot be operational at $\mathrm{THz}$ regime.

\section{ACKNOWLEDGEMENTS}

The present work is funded by Science and Engineering Research Board (SERB), Government of India, through Early Career Research (ECR) Award scheme to Dr. A. Biswas (Grant Number: ECR/2017/000024/ES). Dr. A. Biswas, Prof. H. Inokawa, Dr. A. Acharyya would like to also thanks the project grant for 2020, Cooperative Research at Research Center of Biomedical Engineering, Tokyo Medical and Dental University, Japan (Grant No 2051) and Indo Japan Joint Project No. DST/INT/JSPS/P-310/2020 funded by DST (International Cooperation Division). Authors are grateful to Prof. Hiroshi Amano, Prof. Manabu Arai, and Mr. Seiya Kawasaki for their fruitful discussions. and H. Inokawa, J. Infrared Milli. Terahz. Wave. 39, 954 (2018).

9. Mass magnetic susceptibility of the elements.

10. Density of the elements.

11. Electrical conductivity of the elements.

12. K. Kunihiro, K. Kasahara, Y. Takahashi, and Y. Ohno, IEEE Electron Dev. Lett. 20 No 12, 608 (1999).

13. S.C. Shiyu, and G. Wang, J. Appl. Phys. 103, 023703 (2008).

14. Electronic Archive: New Semiconductor Materials, Characteristics and Properties (Accessed in January 2021).

15. B.V. Zeghbroeck, Principles of Semiconductor Devices, Colorado Press, USA, 2011.

16. P. Zhang and Y.Y. Lau, Appl. Phys. Lett. 104, 204102 (2014).

17. A. Acharyya, S. Banerjee, and J.P. Banerjee, J. Comput. Electron.12 No 3, 511 (2013). 


\title{
Застосування структури зі зворотним подвійним дрейфом для виготовлення GaN IMPATT діода, що працюе у терагерцевому діапазоні
}

\author{
Sahanowaj Khan ${ }^{1}$, Rishav Dutta ${ }^{2}$, Aritra Acharyya ${ }^{3}$, Arindam Biswas ${ }^{2}$, \\ Hiroshi Inokawa ${ }^{4}$, and Rudra Sankar Dhar ${ }^{1}$ \\ ${ }^{1}$ Department of Electronics and Communication Engineering, National Institute of Technology, Chaltlang, \\ Aizawl, Mizoram 796012, India \\ ${ }^{2}$ School of Mines and Metallurgy, Kazi Nazrul University, Asansol, Burdwan, West Bengal 713340, India \\ ${ }_{3}^{3}$ Department of Electronics and Communication Engineering, Cooch Behar Government Engineering College, \\ Cooch Behar, West Bengal 736170, India \\ ${ }^{4}$ Research Institute of Electronics, Shizuoka University, Hamamatsu 4328011, Japan
}

\begin{abstract}
Корисність структури зі зворотною областю подвійного дрейфу (DDR) була вивчена для виготовлення IMPATT діода з нітриду галію $(\mathrm{GaN})$, що працюе на частоті 1,0 ТГц. Для перевірки можливостей структур з традиційною (нормальною) та зворотною DDR у терагерцовому діапазоні проведено моделювання статичних та великих сигналів. Виявлено, що функціонування GaN IMPATT діода можливе тільки у структурі зі зворотною DDR через більш низьке значення послідовного опору в порівнянні зі структурою з нормальною DDR. GaN IMPATT діод з нормальною DDR не може працювати у терагерцовому діапазоні. Однак раніше автори розрахували послідовний опір GaN IMPATT діода з традиційною DDR, призначеного для роботи на частоті 1,0 ТГц. Вони не враховували струм, що протікае, та опір розтіканню на омічних металевих контактах. Саме тому їх результати були помилковими. Отримані ними результати дозволяють зробити висновок, що GaN IMPATT діод з традиційною DDR у терагерцовому діапазоні може створювати достатній ефективний негативний опір, оскільки його послідовний опір залишається в діапазоні 1,5-2,0 Ом. У цій статті автори запропонували IMPAТT структуру зі зворотною DDR виключно для матеріалу GaN і терагерцового діапазону частот. Використовуючи цю структуру зі зворотною $\mathrm{DDR}, p^{+}-\mathrm{GaN} \sim \mathrm{Ni} / \mathrm{Au}$ може отримати достатню площу контакту, так що опір анодного контакту буде мінімізовано. Розроблена авторами несинусоїдальна модель великого сигналу, що збуджується напругою, була використана для дослідження властивостей статичних (постійних) і великих сигналів структур з традиційною та зворотною DDR на частоті 1,0 ТГц. Це дослідження відкривае новий горизонт для вчених і дослідників у терагерцовому діапазоні.
\end{abstract}

Ключові слова: Область подвійного дрейфу (DDR), GaN, IMPATT, Зворотна DDR, Терагерцовий. 